\title{
Role of $\mathbf{T}$ follicular helper cells and their associated molecules in the pathogenesis of chronic hepatitis $B$ virus infection
}

\author{
TONGJING XING, HONGTAO XU and WENQING YU \\ Department of Infectious Diseases, Taizhou People's Hospital, Taizhou, Jiangsu 225300, P.R. China
}

Received October 15, 2012; Accepted December 13, 2012

DOI: $10.3892 / \mathrm{etm} .2012 .864$

\begin{abstract}
In this study, we investigated the roles of $\mathrm{T}$ follicular helper (TFH) cells and related molecules in the pathogenesis of chronic hepatitis B virus (HBV) infection. The levels of circulating TFH cells and their surface CD40 ligand (CD40L), as well as $\mathrm{CD} 19^{+} \mathrm{B}$ cells and their surface CD40 expression were detected by flow cytometry. Peripheral blood plasma interleukin (IL)-21 levels were detected by enzyme-linked immunosorbent assay (ELISA). Compared with hepatitis B surface antibody (HBsAb) ${ }^{-}$and $\mathrm{HBsAb}^{+}$healthy controls, the percentage of TFH cells and their surface CD40L expression significantly increased in patients with chronic HBV infection, particularly those with chronic hepatitis $\mathrm{B}(\mathrm{P}<0.05)$. The percentage of $\mathrm{CD} 19^{+} \mathrm{B}$ cells significantly increased in chronic hepatitis B patients and CD40 expression levels on the $\mathrm{CD} 19^{+} \mathrm{B}$ cell surface in chronic HBV infection decreased compared with those in the healthy controls $(\mathrm{P}<0.05)$. Compared with the healthy controls, the plasma IL-21 level in chronic hepatitis B patients was significantly increased in chronic HBV carriers and decreased in inactive hepatitis $B$ surface antigen $(\mathrm{HBsAg})$ carriers $(\mathrm{P}<0.05)$. The TFH cell percentage, $\mathrm{B}$ cell percentage and IL-21 expression did not significantly differ between the hepatitis B e-antigen $(\mathrm{HBeAg})^{-}$and $\mathrm{HBeAg}^{+}$chronic hepatitis $\mathrm{B}$ groups $(\mathrm{P}>0.05)$. The abnormal expression of TFH cells and IL-21 is related to the dysfunction of immune response during chronic HBV infection. The interaction of $\mathrm{CD}_{19}{ }^{+} \mathrm{B}$ cells with TFH cells via their CD40 and CD40L molecules may also play an important role in this process.
\end{abstract}

\section{Introduction}

Chronic hepatitis B (CHB) is an infectious disease that severely harms individuals worldwide. Although new cases

Correspondence to: Professor Tongjing Xing, Department of Infectious Diseases, Taizhou People's Hospital, 399 Hailing South Road, Taizhou, Jiangsu 225300, P.R. China

E-mail:xingtj518@sina.com

Key words: $\mathrm{T}$ follicular helper cells, interleukin-21, chronic hepatitis B of hepatitis B virus (HBV) infection are greatly reduced by the application of a hepatitis $B$ vaccine, $>350$ million individuals are infected with $\mathrm{HBV}$ worldwide. Persistent HBV infection may lead to cirrhosis or hepatocellular carcinoma, which threaten the lives of patients (1). Virus-host interactions, particularly the virus-specific T-cell response, are the key factors accounting for the pathogenesis of HBV infection. In contrast to the strong and multispecific T-cell responses observed during acute self-limited HBV infection, patients with $\mathrm{CHB}$ tend to have weak and narrowly focused immune responses (2).

$\mathrm{CD}^{+} \mathrm{T}$ cells play a vital role in adaptive immune responses. They help B cells produce antibodies and undergo class-switching, as well as affinity maturation. They recruit and activate $\mathrm{CD} 8^{+} \mathrm{T}$ cells, macrophages and other effector cells. $\mathrm{T}$ helper cells, differentiated from naive $\mathrm{CD} 4^{+} \mathrm{T}$ cells, are classified into four major lineages based on their function, pattern of cytokine secretion and expression of specific transcription factors. The lineages are Th1, Th2, Th17 and T regulatory cells $(3,4)$. The assistance of antibody production by $\mathrm{T}$ cells is a fundamental aspect of immune responses. An improved understanding of the cellular and molecular mechanisms of $\mathrm{T}$ cell actions has only recently emerged. A subset of $\mathrm{T}$ cells named $\mathrm{T}$ follicular helper cells (TFH cells) aid B cells and represents one of the largest and most important subsets of effector $\mathrm{T}$ cells in lymphoid tissues $(5,6)$. The features of TFH cells include CXC chemokine receptor 5 (CXCR5) expression, inducible co-stimulator (ICOS), location/migration (B cell follicles) and function (B cell help). TFH cells produce a 'helper' cytokine, interleukin (IL)-21, which stimulates $\mathrm{B}$ cells to differentiate into antibody-forming cells via the IL-21 receptor. The dysregulation of TFH cell function likely contributes to the pathogenesis of immune-related diseases (7).

Humoural immune responses following HBV infection are significant in the pathogenesis of HBV infection. Hepatitis B surface antigen (HBsAg)-specific antibodies neutralise and mediate protective immunity. HBV-specific antibodies are indicators of specific stages of the disease. Hepatitis B core antigen ( $\mathrm{HBcAg}$ )-specific immunoglobulin $\mathrm{G}(\mathrm{IgG})$ and HBsAg-specific antibodies persist for life following clinical recovery (8). TFH cells are a special subset of $\mathrm{T}$ helper cells that regulate humoural immune responses. However, the role of TFH cells in the pathogenesis of HBV infection is unclear. Therefore, in the present study, the levels of TFH cells and related molecules were detected in various types of chronic 

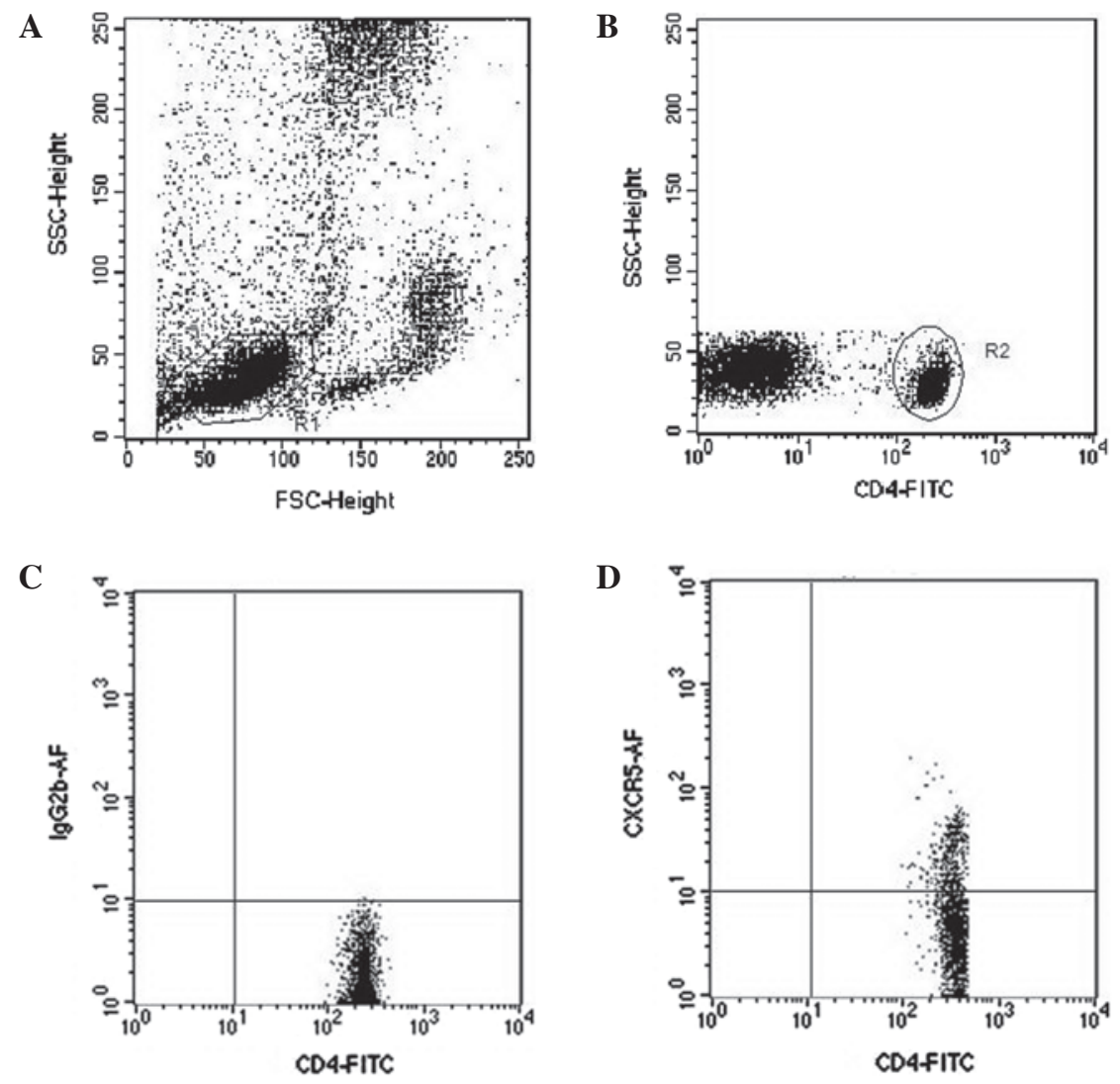

Figure 1. Flow cytometry analysis of TFH cells. (A) Analysis of lymphocyte cells. R1, lymphocyte cell population; (B) analysis of the CD4+ T cell subset. R2, CD4 ${ }^{+} \mathrm{T}$ cell subset population; (C) analysis of TFH cells (isotype control); (D) analysis of TFH cells (CD4 ${ }^{+}$CXCR5 ${ }^{+}$cells). TFH, T follicular helper; CXCR5, CXC chemokine receptor 5.

HBV infection by flow cytometry and enzyme-linked immunosorbent assay (ELISA). The purpose was to investigate the role of TFH cells and related molecules in the pathogenesis of CHB.

\section{Materials and methods}

Subjects. Blood samples were obtained with informed consent from 85 patients infected with HBV and 44 healthy controls at the Taizhou People's Hospital from June to December 2011. There were 42 patients with CHB (male to female ratio, 29:13; average age, $40.7 \pm 11.2$ years) and $43 \mathrm{HBV}$ carriers (male to female ratio, 28:15; average age, $41.3 \pm 11.6$ years). Of the 42 patients with $\mathrm{CHB}, 18$ hepatitis $\mathrm{B}$ extracellular antigen $(\mathrm{HBeAg})^{+}$patients and $24 \mathrm{HBeAg}^{-}$patients were included. Of the $43 \mathrm{HBV}$ carriers, 21 chronic HBV carriers and 22 inactive HBsAg carriers were included. The protocol was approved by the ethics committee of the hospital. The diagnostic criteria were based on the 2010 Chronic Hepatitis B Prevention Guide of China (9). All patients tested negative for antibodies against hepatitis A, C, D and E viruses, as well as human immunodeficiency virus. Patients with a history and clinical features of drug-induced liver injury, alcoholic hepatitis and steatohepatitis were also excluded. Any patients who had been treated with nucleoside/nucleotide analog antiviral or immunomodulatory drugs in the previous six months were excluded. There were 22 cases that were hepatitis B surface antibody $(\mathrm{HBs} \mathrm{Ab})^{+}$following inoculation with a hepatitis $\mathrm{B}$ vaccine (male to female ratio, 13:9; average age, 38.7 \pm 10.3 years) and $22 \mathrm{HBsAb}^{-}$cases who had not been inoculated with a hepatitis $\mathrm{B}$ vaccine (male to female ratio, 10:12; average age, $40.5 \pm 10.6$ years) included as healthy controls. Subjects who were $\mathrm{HBeAb}^{-}$and/or $\mathrm{HBcAb}^{+}$were excluded.

Flow cytometry analysis. Sodium citrate-treated whole blood $(100 \mu \mathrm{l})$ was added to $10 \mu \mathrm{l}$ Alexa Fluor 647-conjugated anti-CXCR5 (BD Company, San Jose, CA, USA) and $10 \mu$ f fluorescein isothiocyanate (FITC)-conjugated anti-CD4 (eBioscience, San Diego, CA, USA), then mixed and incubated for $30 \mathrm{~min}$ at room temperature. Erythrocytes were lysed by adding $2 \mathrm{ml}$ fluorescence-activated cell sorting (FACS) lysing solution. The samples were analyzed on a FACS cytometer using CellQuest ${ }^{\mathrm{TM}}$ software (Fig. 1). CD40L-PE/CD40-PE and CD19-FITC were purchased from eBioscience. The expression of CD40L on the surface of TFH cells and CD40 on the surface of $\mathrm{CD} 19^{+} \mathrm{B}$ cells were detected as described above.

Cytokine detection. The level of IL-21 in stored peripheral plasma was evaluated by ELISA. The kits were purchased from eBioscience and used according to the manufacturer's instructions. The detection range for IL-21 in this kit was $16-2000 \mathrm{ng} / \mathrm{l}$.

Detection of HBV DNA and serum markers. The levels of HBV DNA were detected by fluorescence quantitative polymerase chain reaction (PCR; lower detection limit, $10^{3}$ copies $/ \mathrm{ml}$; 
A

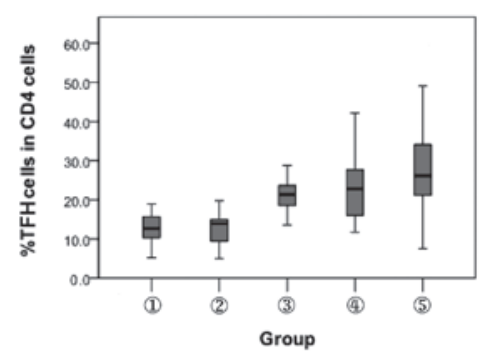

B

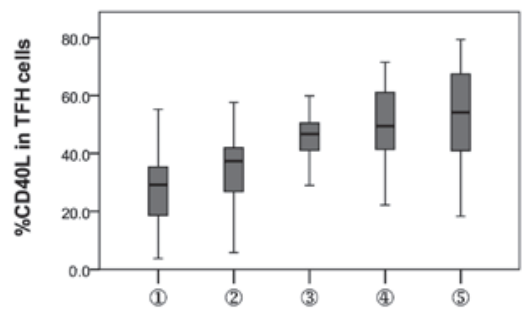

C

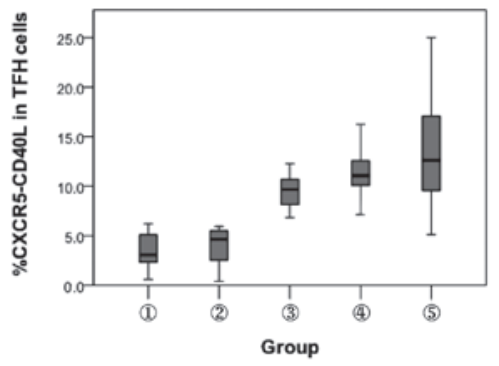

Figure 2. Comparison of the expression of TFH cells and their surface CD40L molecule. 1 , HBsAb healthy controls; $2, \mathrm{HBsAb}^{+}$healthy controls; 3, chronic HBV carriers; 4, inactive HBsAg carriers and 5, chronic hepatitis B. (A) Percentage of TFH cells. $\mathrm{P}<0.01$, between groups 1,2 and 3, 4, 5. (B) Percentage of CD40L. $\mathrm{P}<0.01$, between groups 1,2 and $3,4,5$. (C) Coexpression of $\mathrm{CXCR}^{+} \mathrm{CD} 40 \mathrm{~L}^{+}$cells. $\mathrm{P}<0.01$, between groups 1,2 and 3, 4, 5. TFH, T follicular helper; HBsAb, hepatitis B surface antibody; HBV, hepatitis B virus; HBsAg, hepatitis B surface antigen; CXCR5, CXC chemokine receptor 5 .

Applied Biosystems, Foster City, CA, USA). HBV PCR fluorescence quantitative detection kits were purchased from Biological Engineering Co., Ltd. (Shanghai, China). The serum markers of HBV, anti-HAV, anti-HCV, anti-HDV and anti-HEV, were detected by ELISA. The kits were purchased from Beijing Yuanpinghao Biotechnology Co., Ltd. (Beijing, China).

Statistical analysis. All values are expressed as the median and quartile interval. Data analysis was conducted using SPSS 17.0 (SPSS Inc., Chicago, IL, USA). Nonparametric tests (Kruskal-Wallis H test) were used for multiple group comparison. The Mann-Whitney U test was used for two independent data. The Spearman correlation was used between variables. $\mathrm{P}<0.05$ was considered to indicate a statistically significant difference.

\section{Results}

Proportion of TFH cells and levels of CD4OL expression on the surface of TFH cells. The proportion of TFH cells gated with $\mathrm{CD}^{+} \mathrm{T}$ cells and CD40L expression level were detected by flow cytometry in 42 patients with $\mathrm{CHB}, 43 \mathrm{HBV}$ carriers and 44 healthy controls. Compared with the $\mathrm{HBsAb}^{-}$and $\mathrm{HBsAb}^{+}$ healthy controls, patients with chronic HBV infection had
A

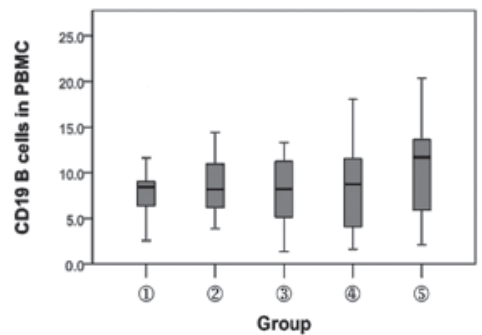

B

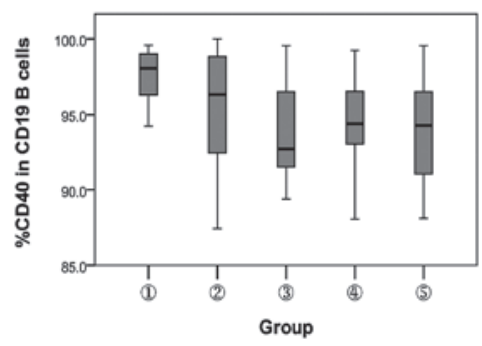

Figure 3. Comparison of the expression of $\mathrm{CD} 19^{+} \mathrm{B}$ cells and their surface $\mathrm{CD} 40$ molecule. $1, \mathrm{HBsAb}^{-}$healthy controls; $2, \mathrm{HBsAb}^{+}$healthy controls; 3, chronic HBV carriers; 4, inactive HBsAg carriers and 5, chronic hepatitis B. (A) Percentage of $\mathrm{CD} 19^{+} \mathrm{B}$ cells. $\mathrm{P}<0.05$, between groups 3,4 and 5 . (B) Percentage of CD40. $\mathrm{P}<0.01$, between groups 1 and 3, 4 and 5. HBsAb, hepatitis B surface antibody; HBV, heptitis B virus; HBsAg, hepatitis B surface antigen; PBMC, peripheral blood mononuclear cells.

significantly increased percentages of TFH cells $(\mathrm{P}<0.01)$. The percentage of TFH cells was higher in the patients with $\mathrm{CHB}$ than in the chronic HBV carriers $(\mathrm{P}<0.01)$. The percentage of CD40L in chronic HBV infected individuals was significantly higher than in the $\mathrm{HBsAb}^{-}$and $\mathrm{HBsAb}^{+}$healthy controls $(\mathrm{P}<0.01)$. The pattern of coexpression of CXCR5 and CD40L in the $\mathrm{CD}^{+} \mathrm{T}$ cells in the different groups was similar to that of the TFH cells. No significant difference was observed in the percentage of TFH cells or CD40L between the $\mathrm{HBsAb}^{-}$and $\mathrm{HBsAb}^{+}$healthy controls (Fig. 2).

Detection of the expression of $\mathrm{CD}_{19^{+}} \mathrm{B}$ cells and their surface CD40 molecules in different subjects. The percentage of $\mathrm{CD} 19^{+} \mathrm{B}$ cells and their surface CD 40 molecule expression were detected by flow cytometry in different subjects. Compared with the $\mathrm{HBsAb}^{-}$and $\mathrm{HBsAb}^{+}$healthy controls, the percentage of $\mathrm{CD} 19^{+} \mathrm{B}$ cells in patients with $\mathrm{CHB}$ increased significantly $(\mathrm{P}<0.05)$. No significant difference was observed between chronic HBV carriers and inactive HBsAg carriers $(\mathrm{P}>0.05)$. The percentage of CD40 molecules on the surface of $\mathrm{CD} 19^{+} \mathrm{B}$ cells in the $\mathrm{CHB}$ patients was lower than that in the $\mathrm{HBsAb}^{-}$healthy controls $(\mathrm{P}<0.01)$. No significant difference was observed among the remaining groups $(\mathrm{P}>0.05$; Fig. 3 ).

Detection of plasma IL-21 expression in different subjects. The plasma IL-21 expression level in the different subjects was detected by ELISA. Compared with the $\mathrm{HBsAb}^{-}$and $\mathrm{HBsAb}^{+}$ healthy controls $(332.7 \pm 202.5$ and $295.3 \pm 108.6 \mathrm{ng} / \mathrm{l})$, plasma IL-21 expression was markedly decreased in the HBV carriers and inactive HBsAg carriers (239.6 195.9 and 215.5 $\pm 132.0 \mathrm{ng} / \mathrm{l}$, respectively; $\mathrm{P}<0.05)$. However, plasma IL-21 expression in the CHB patients $(375.6 \pm 192.3 \mathrm{ng} / \mathrm{l})$ was significantly higher than that in the $\mathrm{HBsAb}^{+}$healthy controls $(\mathrm{P}<0.05)$ and $\mathrm{HBV}$ carriers or inactive HBsAg carriers $(\mathrm{P}<0.01)$. No significant difference was identified among the other groups ( $\mathrm{P}>0.05$; Fig.4). 
Table I. Comparison of the levels of TFH and IL-21 between the $\mathrm{HBeAg}$ and $\mathrm{HBeAg}^{+}$groups.

\begin{tabular}{lcccc}
\hline Group & $\mathrm{n}$ & TFH cell (\%) & CD40L (\%) & IL-21 (ng/l) \\
\hline $\mathrm{HBeAg}^{-}$ & 24 & $25.2 \pm 15.2$ & $51.4 \pm 18.0$ & $402.2 \pm 156.7$ \\
$\mathrm{HBeAg}^{+}$ & 18 & $28.0 \pm 12.0^{\mathrm{a}}$ & $54.8 \pm 31.5^{\mathrm{a}}$ & $344.5 \pm 261.2^{\mathrm{a}}$ \\
\hline
\end{tabular}

${ }^{\mathrm{a}} \mathrm{P}>0.05$, compared with the $\mathrm{HBeAg}^{+}$group. $\mathrm{TFH}, \mathrm{T}$ follicular helper; IL, interleukin; HBeAg, hepatitis B e-antigen.

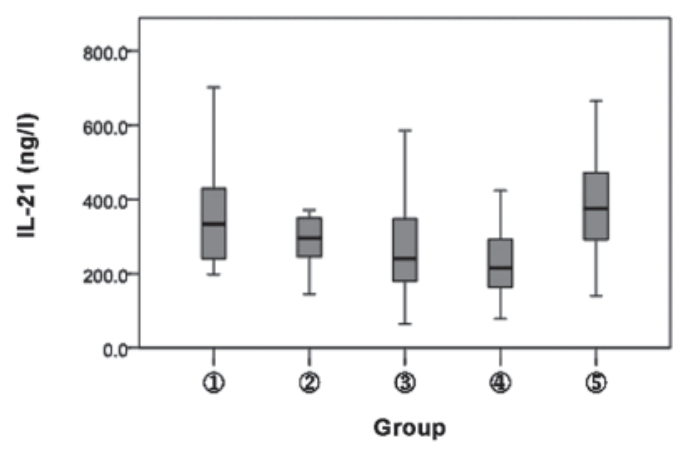

Figure 4. Comparison of IL-21 expression levels. 1, HBsAb- healthy controls; 2, $\mathrm{HBsAb}^{+}$healthy controls; 3 , chronic HBV carriers; 4, inactive HBsAg carriers and 5 , chronic hepatitis B. $\mathrm{P}<0.05$, between the levels of IL- 21 in groups 1 and $3 ; 2$ and 4,$5 ; \mathrm{P}<0.01$, between the levels of IL-21 in groups 1 and $4 ; 3$, 4 and 5. IL, interleukin; HBsAb, hepatitis B surface antibody; HBV, hepatitis B virus; $\mathrm{HBsAg}$, hepatitis B surface antigen.

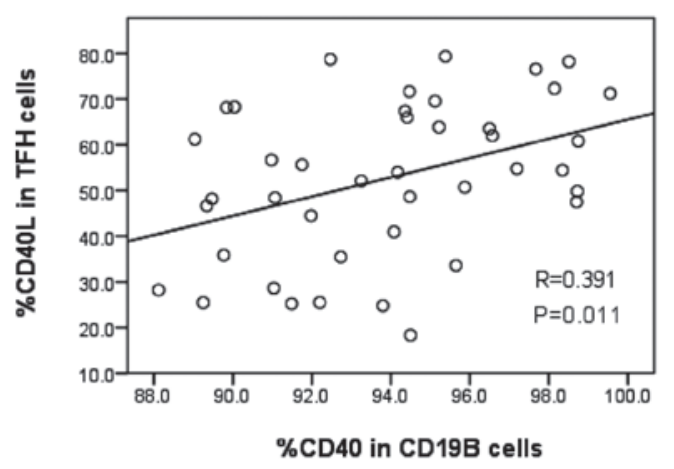

Figure 5. Correlation between the levels of CD40L and CD40 expression. $\mathrm{TFH}, \mathrm{T}$ follicular helper.

Correlation of TFH cells, CD19+ B cells and IL-21 level with the clinical indicators of $C H B$ patients. The levels of HBV viral load, alanine aminotransferase (ALT) and aspartate aminotransferase (AST) of the CHB patients were $5.7 \pm 2.8$ $(\log 10$ copies $/ \mathrm{ml}), 102 \pm 227.1 \mathrm{U} / 1$ and $88 \pm 152.2 \mathrm{U} / 1$, respectively. No significant correlation was identifed among the percentage of TFH cells, CD19+ B cells, IL-21 level, HBV viral load level, ALT and AST $(\mathrm{P}>0.05)$. There were $24 \mathrm{HBeAg}^{-}$and $18 \mathrm{HBeAg}^{+}$cases among 42 patients with $\mathrm{CHB}$. No significant differences were identified in the percentage of TFH cells and the expression level of CD40L molecules between the $\mathrm{HBeAg}$ and $\mathrm{HBeAg}^{+}$groups $(\mathrm{P}>0.05)$. The IL-21 expression level was $402.2 \pm 156.7 \mathrm{ng} / \mathrm{l}$ in the HBeAg- group and $344.5 \pm 261.2 \mathrm{ng} / \mathrm{l}$ in the $\mathrm{HBeAg}^{+}$group. No significant difference was identified between the two groups ( $\mathrm{P}>0.05$; Table I).

Correlation between the TFH cells and B cells in patients with $C H B$. The percentage of TFH cells in $\mathrm{CD}^{+} \mathrm{T}$ cells was $26.1 \pm 13.3 \%$ in the 42 patients with CHB. The level of CD40L expression in the TFH cells was $54.2 \pm 27.9 \%$. The percentage of $\mathrm{CD} 19^{+} \mathrm{B}$ cells in peripheral blood mononuclear cells was $11.7 \pm 7.8 \%$. The level of CD40 molecular expression in $\mathrm{CD} 19^{+} \mathrm{B}$ cells was $94.3 \pm 5.4 \%$. A positive correlation was observed between CD40L expression in TFH cells and CD40 expression in $\mathrm{CD} 19^{+} \mathrm{B}$ cells ( $\mathrm{r}=0.391, \mathrm{P}=0.011$; Fig. 5). No correlation was observed between the percentage of TFH cells and $\mathrm{CD} 19^{+} \mathrm{B}$ cells $(\mathrm{r}=0.172, \mathrm{P}=0.276)$.

\section{Discussion}

$\mathrm{T}$ helper cells are required for B cell-mediated humoural immune responses. Previous studies have shown that Th 2 cells play a key role in aiding B cell responses; however, TFH cells have been recently recognised as the major subset that aids $\mathrm{B}$ cell responses. A number of studies have reported on the role of TFH cells in immune-related disease; however, few studies have described their role in chronic HBV infection $(7,10)$. Feng et al (11) identified that TFH cells are involved in the immune response in HBV infection and their increase in number reflects the activation of the immune response. The results of the present study revealed that the percentage of TFH cells increased in patients with chronic HBV infection compared with healthy subjects. The percentage of TFH cells in the CHB patients was higher than that in the chronic HBV carriers and inactive $\mathrm{HBsAg}$ carriers. These results suggest that the elevation of TFH cells in CHB patients is associated with the activation of anti-HBV immune responses and are consistent with the study by Feng et al. Some studies showed that the expression of CXCR5 in the activation of T cells is transient and rare, and is only persistently expressed in TFH cells $(6,12)$. Therefore, the effect of $\mathrm{CD} 4^{+} \mathrm{T}$ cell activation on the changes of TFH during HBV infection may be excluded.

The high expression level of CD40L in TFH cells binding to CD40 in B cells plays an important role in stimulating $\mathrm{B}$ cell proliferation, differentiation and immunoglobulin class switching (13). Wu and Wen demonstrated that the percentage of $\mathrm{CD} 19^{+} \mathrm{B}$ cells in $\mathrm{CHB}$ atients was significantly higher than in healthy controls (14). In the present study, compared with $\mathrm{HBsAb}^{-}$healthy controls, the percentage of $\mathrm{CD}^{+} 9^{+} \mathrm{B}$ cells was elevated and the percentage of CD40 molecules on the surface of $\mathrm{CD} 19^{+} \mathrm{B}$ cells decreased in patients with $\mathrm{CHB}$. The percentage of CD40L molecules on the surface of TFH cells in CHB patients was significantly elevated. There was a positive correlation between the level of CD40L expression in TFH cells and CD40 expression in $\mathrm{CD} 19^{+} \mathrm{B}$ cells. These results suggest that the activation of $\mathrm{B}$ lymphocytes in patients with CHB may be involved in the dysfunction of the humoural immune response of CHB.

TFH cells produce numerous cytokines, including IL-4, $-10,-17$ and -21 , among which the most important is IL-21. IL-21 is the major cytokine of TFH cells and also a key factor affecting the formation of germinal centres. IL-21 is also known as TFH cell helper factor (15). Hu et al (16) reported that IL-21 
promotes B-cell proliferation and $\mathrm{HBeAg}^{-} \mathrm{IgG}$ secretion in $\mathrm{CHB}$ patients and may play a role in the serological conversion of $\mathrm{HBeAg}$ to $\mathrm{HBeAb}$. The results of the current study revealed that the IL-21 level decreased in the plasma of HBV and inactive HBsAg carriers; however, it increased in CHB patients. These results suggest that IL-21 expression may be correlated with the immune response against HBV infection, similar to the alteration of TFH cells. There was no clear difference between the IL-21 levels of the $\mathrm{HBeAg}^{+}$and $\mathrm{HBeAg}^{-}$patients. No significant correlation was identified between IL-21 expression and the levels of HBV DNA, ALT and AST, which differs from the results of the study by Feng et al (11). The cause of these discrepancies may be related to patient selection and the research methods used.

In addition to promoting the differentiation of TFH cells and stimulating $\mathrm{B}$ cell proliferation, IL-21 also promotes the generation of interferon (IFN) $-\gamma$ and counteracts regulatory T cell-mediated immune suppression. Additionally, it enhances $\mathrm{CD}^{+} \mathrm{T}$ cell and natural killer (NK) cell cytotoxicity (17). A previous study demonstrated that IL-21 participates in the immune response of viral infection clearance in acute HBV infection. However, this phenomenon is not observed in CHB patients (18). Decreased IL-21 production may block the key function of $\mathrm{CD}^{+} \mathrm{T}$ cells and $\mathrm{B}$ cell response, influencing the immune response against $\mathrm{HBV}$. The results of the current study revealed that the IL-21 level decreased in chronic $\mathrm{HBV}$ carriers and inactive $\mathrm{HBsAg}^{+}$carriers and the percentage of TFH cells was significantly elevated. These results suggest that the activity of $\mathrm{TFH}$ cells may decrease in chronic $\mathrm{HBV}$ and inactive $\mathrm{HBsAg}^{+}$carriers. The level of IL-21 and TFH cells synchronously increased in the CHB patients. Yi et al (19) reported that IL-21 and IL-21-producing cells (TFH cells) are important in generating and maintaining multi-functional $\mathrm{CD}^{+} \mathrm{T}$ cells to clear the viral infection. The TFH cell number and/or abnormal function, as well as IL-21 expression deficiency, may be closely associated with the chronicity of hepatitis B virus infection. However, several studies have demonstrated that Th17 cells, $\mathrm{CD}^{+} \mathrm{T}$ cells and NK T cells also produce amounts of IL-21, in addition to TFH cells (20). The effect of these cells on the expression level of IL-21 requires further research.

In conclusion, the results of the present study suggest that the abnormal expression of TFH cells and IL-21 is related to the dysfunction of the immune response during chronic HBV infection. The interaction of $\mathrm{CD}_{19}{ }^{+} \mathrm{B}$ cells with TFH cells via their CD40 and CD40L molecules may be significant in this process.

\section{References}

1. Hong Y, Peng Y, Mi M, Xiao H, et al: Lentivector expressing HBsAg and immunoglobulin Fc fusion antigen induces potent immune responses and results in seroconversion in $\mathrm{HBsAg}$ transgenic mice. Vaccine 29: 3909-3916, 2011.

2. Chisari FV: Rous-Whipple Award Lecture. Viruses, immunity and cancer: lessons from hepatitis B. Am J Pathol 156: 1117-1132, 2000.

3. Zhu J and Paul WE: Heterogeneity and plasticity of Thelper cells. Cell Res 20: 4-12, 2010.

4. Durrant DM and Metzger DW: Emerging roles of T helper subsets in the pathogenesis of asthma. Immunol Invest 39: 526-549, 2010.

5. Breitfeld D, Ohl L, Kremmer E, Ellwart J, et al: Follicular $\mathrm{B}$ helper T cells express CXC chemokine receptor 5, localize to $\mathrm{B}$ cell follicles and support immunoglobulin production. J Exp Med 192: 1545-1552, 2000.

6. Schaerli P, Willimann K, Lang AB, Lipp M, et al: CXC chemokine receptor 5 expression defines follicular homing $\mathrm{T}$ cells with B cell helper function. J Exp Med 192: 1553-1562, 2000.

7. Crotty S: Follicular helper CD4 T cells (TFH). Annu Rev Immunol 29: 621-663, 2011.

8. Rehermann B and Nascimbeni M: Immunology of hepatitis B virus and hepatitis $C$ virus infection. Nat Rev Immunol 5: 215-229, 2005

9. Chinese Society of Hepatology and Chinese Society of Infectious Diseases, Chinese Medical Association: The guideline of prevention and treatment of chronic hepatitis B (2010 version). Zhonghua Gan Zang Bing Za Zhi 19: 13-24, 2011 (In Chinese).

10. Fazilleau N, Mark L, McHeyzer-Wilimas LJ and McHeyzer-Williams MG: Follicular helper cells: lineage and locations. Immunity 30: 324-335, 2009.

11. Feng J, Lu L, Hua C, Qin L, et al: High frequency of $\mathrm{CD}^{+}$ $\mathrm{CXCR}^{+}$TFH cells in patients with immune-active chronic hepatitis B. PLoS One 6: e21698, 2011.

12. Haynes NM, Allen CD, Lesley R, Ansel KM, et al: Role of CXCR5 and CCR7 in follicular Th cell positioning and appearance of a programmed cell death gene-1 high germinal center-associated subpopulation. J Immunol 179: 5099-5108, 2007.

13. Vinuesa CG, Tangye SG, Moser B and Mackay CR: Follicular $B$ helper $T$ cells in antibody responses and auto immunity. Nature Rev Immunol 5: 853-865, 2005.

14. Wu Y and Wen J: Role of B lymphocytes in patients with chronic hepatitis B. Clinical Focus 21: 31-33, 2006 (In Chinese).

15. Spolski R and Leonard WJ: IL-21 and T follicular helper cells. Int Immunol 22: 7-12, 2010.

16. Hu C, Chen C, Tan X and Shi T: Effects of IL-21 on B lymphocytes proliferation and $\mathrm{HBeAb}$ production in chronic hepatitis B patients. J Immunol 27: 126-129, 2011 (In Chinese).

17. Yi JS, Cox MA and Zajac AJ: Interleukin-21: a multifunctional regulator of immunity to infections. Microbes Infect 12: 1111-1119, 2010.

18. Publicover J, Goodsell A, Nishimura S, Vilarinho S, et al: IL-21 is pivotal in determining age-dependent effectiveness of immune responses in a mouse model of human hepatitis B. J Clin Invest 121: 1154-1162, 2011.

19. Yi JS, Du M and Zajac AJ: A vital role for interleukin-21 in the control of a chronic viral infection. Science 324: 1572-1576, 2009.

20. Coquet JM, Kyparissoudis K, Pellicci DG, Besra G, et al: IL-21 is produced by NKT cells and modulates NKT cell activation and cytokine production. J Immunol 178: 2827-2834, 2007. 